Info Artikel

Diterima : 01 April 2020

Disetujui : 15 Juli 2020

Dipublikasikan : 20 Juli 2020

\title{
Kalimat Interogatif dalam Bahasa Serawai Masyarakat Seluma
}

\author{
Aceng Joyo ${ }^{1 凶}$ \\ ${ }^{1}$ SMK Negeri 1 Seluma, Bengkulu \\ 1aceng_joyo@yahoo.com
}

\begin{abstract}
This research is important to be carried out as a form of preservation and retention of regional languages that is almost extinct in the millennial era and as a form of re-introduction to the next generation. The purpose of this research is to describe the interrogative sentences in Serawai, especially in Seluma Regency. The research method used was a descriptive qualitative method in the use of interrogative sentences in the Serawai tribe of Seluma Regency. The results revealed that Seluma community has sentences and interrogative words that apply to communicate between the speaker and the speech partner so as to communicate effectively. The interrogative sentences in Serawai for in, to, whereof (di, ke and jak), asking question for what (dio); for who (sapo); for when (kebilo); for in, to, from (di, ke and jak); for how many (begapo); for how (luakmano); and for why (ngapo). These types of question words function and aim to ask questions and require answers or action between the speaker and the speech partner.
\end{abstract}

Keywords: kalimat, interogatif, Seluma

\begin{abstract}
Abstrak : Penelitian ini penting dilakukan sebagai bentuk pelestarian dan pemertahanan bahasa daerah yang hampir punah di era milenial dan sebagai bentuk pengenalan kembali pada generasi penerus. Tujuan penelitian adalah untuk mendeskripsikan kalimat interogatif dalam bahasa Serawai khususnya di Kabupaten Seluma. Metode penelitian yang digunakan adalah metode kualitatif deskiptif dalam pemakaian kalimat interogatif pada suku Serawai Kabupaten Seluma. Hasil penelitian menunjukkan bahwa masyarakat Seluma mempunyai kalimat dan kata bantu tanya yang berlaku untuk berkomunikasi antara penutur dan mitra tutur. Hal tersebut dilakukan dengan harapan komunikasi menjadi efektif. Kalimat interogatif dalam bahasa Serawai masyarakat Seluma kata tanya di, ke, dari mana (di, ke dan jak), kata tanya apa (dio); kata tanya siapa (sapo); kata tanya kapan (kebilo); kata tanya di, ke, dari (di, ke dan jak); kata tanya berapa (begapo); kata tanya bagaimana (luakmano); dan Kata tanya mengapa (ngapo). Jenis kata tanya tersebut befungsi dan bertujuan untuk menanyakan sesuatu dan memerlukan jawaban atau tindakan antara penutur dan mitra tutur.
\end{abstract}

Kata Kunci : kalimat, interogatif, seluma

Sitasi Artikel:

Joyo, A. (2020). Kalimat Interogatif dalam Bahasa Serawai Masyarakat Seluma. Disastra: Jurnal Pendidikan Bahasa dan Sastra Indonesia, 2(2), 164-170. doi:http://dx.doi.org/10.29300/disastra.v2i2.3044 


\section{Pendahuluan}

Bahasa merupakan salah satu alat interaksi sosial. Terdapat dua bahasa, yaitu bahasa tulis dan bahasa lisan. Variasi bahasa tulis tidak sedinamis variasi bahasa yang dilisankan. Bahasa lisan hidup pada interaksi sosial sebab pada waktu seseorang berinteraksi sosial yang berhubungan dengan bahasa, orang tidak lagi berpikir, apakah kata-kata yang digunakan memenuhi kaidah pemakaian bahasa atau tidak. Setiap bahasa mempunyai ketetapan atau kesamaan dalam hal tata bunyi, tata bentuk, tata kata, tata makna, dan tata kalimat. Kalimat merupakan satuan bahasa yang berisi suatu "pikiran" atau "amanat" yang lengkap (Chaer, 2011: 327). Lengkap disini berarti kalimat mengandung subjek, predikat, objek dan keterangan. Subjek dan predikat merupakan unsur yang harus ada di dalam setiap kalimat, sedangkan unsur objek dan keterangan tidak harus selalu ada.

Selain unsur subjek, predikat, objek dan keterangan setiap kalimat harus dilengkapi dengan unsur intonasi yang lazim disebut dengan intonasi kalimat. Di dalam bahasa tulis intonasi kalimat dilambangkan dengan tanda baca titik (.), tanda seru (!), dan tanda tanya (?). Jika dilihat dari segi makna yang dikandungnya, kalimat dibedakan atas jenis kalimat. Salah satu jenis kalimat tersebut adalah kalimat tanya. Kalimat tanya ini banyak ditemukan dalam penggunaan bahasa Indonesia percakapan. Kalimat tanya dapat diartikan sebagai kalimat yang mengandung intonasi dan makna pertannyaan (Ali, 1997: 43). Hal tersebut sejalan dengan batasan yang dikemukakan oleh Moeliono (1997: 288). Bahwa: "kalimat tanya yang biasa dinamakan kalimat interogratif adalah kalimat yang isinya menanyakan sesuatu atau seseorang. Jika ingin mengetahui jawaban terhadap suatu masalah atau keadaan, maka dapat dinyatakan dengan memakai kalimat tanya".

Pembentukan kalimat tanya dapat dilakukan dengan lima macam cara. Kelima macam cara pembentukan kalimat tanya yang dimaksud adalah (1) dengan menambahkan kata tanya apa atau apakah, (2) dengan membalikkan urutan kata, (3) dengan memakai kata bukan atau tidak, (4) dengan mengubah intonasi kalimat, dan (5) dengan memakai kata tanya (Markhamah, 2009: 74). Penggunaan kalimat tanya yang benar akan mendapatkan jawaban yang dikehendaki.

Selain untuk menanyakan tentang sesuatu, kalimat tanya juga berfungsi untuk menyatakan berbagai hal. Sebuah kalimat tanya adakalanya dapat menyatakan lebih dari satu macam fungsi. Misalnya, selain menyatakan pelarangan, kalimat tanya itu juga menyatakan perintah dan terkadang penutur bermaksud menyatakan kekecewaan atas apa yang dilakukan lawan tutur. Melihat adanya keragaman fungsi tutur kalimat tanya itu dapat dipahami bahwa bahasa selain berfungsi informatif juga menjalankan fungsi ekspresif.

Suku Serawai adalah suku bangsa dengan populasi terbesar kedua yang hidup di daerah Bengkulu. Sebagian besar masyarakat suku Serawai berdiam di Kabupaten Bengkulu Selatan, yakni di Kecamatan Sukaraja, Seluma, Talo, Pino, Kelutum, Manna, dan Seginim. Suku Serawai yang ada di Kabupaten Seluma menetap di 14 kecamatan hasil pemekaran dari Kabupaten Bengkulu Selatan.

Suku Serawai di Kabupaten Seluma dialektologi bahasanya menggunakan dialek berbunyi $\mathrm{o}$. Misalnya mengapa=ngapo, dan 
apa=dio. Berbeda dengan suku Serawai yang ada di wilayah Bengkulu Selatan atau Kaur. Pada suku Serawai juga mempunyai etnik dan keunikan bahasa dan jenis kalimat. Salah satu kalimat yang unik adalah kalimat tanya yang sering dipakai masyarakat di Kabupaten Seluma. Pada saat ini bahasa mengalami perkembangan zaman yang pesat, hal ini disebabkan banyak faktor.

Dari pandangan penulis, faktor ini disebabkan dua faktor, yaitu faktor intern masyarakat suku Serawai yang sangat terbuka dan tergolong mudah bersosiaisasi. Selanjutnya, faktor ekstren yaitu faktor dari luar yaitu pengaruh pergaulan anak-anak merantau ke daerah lain dan pengaruh teknologi terhadap pemakai bahasa yang secara tidak sadar mulai melupakan bahasa sendiri. Dari uraian di atas, peneliti sangat tertarik mengkaji: "Kalimat Interogatif Bahasa Serawai Masyarakat Seluma".

\section{Metode Penelitian}

Penelitian ini merupakan penelitian kualitatif deskriptif, yaitu mengumpulkan, menganalisis, dan mengajukan data secara objektif mengenai objek penelitian, yaitu kalimat interogatif pada suku Serawai Kabupaten Seluma. Penelitian ini dilakukan berdasarkan pengalaman dan lingkungan peneliti yang terjadi di masyarakat berlangsung dengan memperhatikan lafal (ucapan), diksi (pemilihan kata), dan struktur kalimat. Metode simak adalah metode pengumpulan data yang dilakukan melalui proses penyimakan atau pengamatan terhadap penggunaan bahasa yang diteliti.

Metode ini hampir sama dengan metode observasi dalam ilmu sosial. Istilah simak di sini bukan hanya berkaitan dengan penggunaan bahasa lisan seperti pidato dan percakapan antar penutur suatu bahasa, tetapi juga termasuk untuk bahasa tulis, yaitu mengamati, membaca, dan memahami bahasa tulis yang ada dalam suatu teks tertulis seperti naskah cerita, berita surat kabar, dan naskah tertulis lainnya. Metode simak dapat diwujudkan dalam bentuk teknik pengumpulan data yang diberi nama sesuai dengan alat yang digunakannya seperti menyadap, melakukan percakapan, merekam, atau mencatat. Dari segi tahapan penggunaannya, teknik-teknik dalam metode simak ini dapat dibedakan menjadi dua jenis teknik, yaitu teknik dasar dan teknik lanjutan. Teknik dasar adalah teknik yang harus digunakan oleh seorang pengumpul data terlebih dahulu sebelum menggunakan teknik berikutnya, yang kemudian disebut teknik lanjutan (Zaim, 2014: 79).

\section{Hasil dan Pembahasan}

Bahasa merupakan unsur yang tidak dapat dipisahkan dengan manusia dalam kehidupan kesehariannya. Dalam melakukan aktivitasnya, manusia tidak terlepas dari menggunakan bahasa. Bahasa merupakan bagian dari kehidupan manusia untuk berkomunikasi sesama manusia. Oleh karena itu, dikatakan bahwa bahasa merupakan alat komunikasi manusia, baik lisan maupun tulisan (Zaim, 2014: 1).

Dalam konteks penggunaan bahasa dalam kehidupan sosial sering sakli kita dengar penggunaan kalimat hingga kata di tengah masyarakat. Begitupula yang beraku pada masyarakat suku Serawai yang ada di Kabupaten Seluma. Pada masyarakat Seluma mempunyai kalimat dan kata bantu tanya yang berlaku untuk berkomunikasi antara penutur dan mitra tutur. Hal tersebut dilakukan dengan harapan komunikasi 
menjadi efektif. Jenis, fungsi dan contoh kalimat tanya interogatif pada masyarakat suku Serawai di Kabupaten Seluma yaitu:

\section{Kata Tanya Apa}

Pada masyarakat suku Serawai Seluma mempunyai pola kalimat tanya apa/apakah adalah dio? Fungsi : untuk menanyakan maksud tertentu atau benda/alat tertentu.

Pertanyaan:

Dio nyo kaba batak tu?

"Apa/kah yang kamu bawa itu?"

Jawaban:

Aku matak deghian

"Saya membawa durian".

Jawaban dari pertanyaan tersebut adalah durian, durian adalah benda berupa jenis buah-buahan.

Jadi, kata tanya dio pada masyarakat Serawai Seluma digunakan untuk menanyakan jenis benda atau kejadian.

Pengunaan kata dio merupakan sebagi bentuk kata tanya apa/apakah dalam masyarakat Serawai Seluma. Dimana penggunaan kata tersebut sering terdengar dalam tindak tutur atau pergaulan seharihari. Kata dio dapat digunakan pada orang tua atau anak.

\section{Kata Tanya Siapa}

Kata siapa pada masyarakat suku Serawai Kabupaten Seluma adalah sapo? Konteks kata sapo bertujuan untuk menanyakan orang baik itu jenis kelamin perempuan/laki-laki.

Fungsi : untuk menanyakan orang.

Pertanyaan:

Sapo yang dapat juaro?
"Siapa yang menjadi juara?"

Jawaban:

Shakila nyo dapat juaro.

"Shakila yang menjadi juara".

Jawaban dari pertanyaan tersebut adalah Shakila. Shakila adalah nama orang jadi kata tanya siapa digunakan untuk menanyakan orang. Pada masyarakat suku Serawai Seluma kata siapa menjadi sapo. Kata sapo juga bagian kata bantu tanya yang menyatakan sapo baik itu pelaku atau berkaitan pada orang. Kata sapo sering sekali digunakan dalam pergaulan seharihari pada masyarakat.

\section{Kata Tanya Kapan}

Kata tanya kapan pada masyarakat Serawai Seluma adalah Kebilo?. Kata kebilo bermaksud untuk menanyakan waktu yang menunjukkan kapan atau kejadian.

Fungsi : untuk menanyakan waktu.

Pertanyaan:

Kebilo datuk sampai?

Kapan kakek datang?

Jawaban:

Pagi datuk datang.

Besok, kakek akan datang.

Jawaban dari pertanyaan tersebut adalah besok. Kata besok merupakan keterangan waktu, jadi kata tanya kapan digunakan untuk menanyakan waktu. Pada masyarakat suku Serawai Seluma penggunaan kata kapan menjadi kata kebilo.

\section{Kata Tanya (di, ke, dari) Mana}

Kata tanya di, ke dan dari pada masyarakat Serawai Seluma adalah dimano, kemano dan kata dari adalah memakai kata jak yang menunjukkan darimana. 
Fungsi: untuk menanyakan tempat/lokasi.

Pertanyaan:

Dimano umah o?

Dimana rumahnya?

Jawaban:

Umah o di Bogor.

Rumahnya di Bogor.

Pertanyaan:

Kemano Emak pegi?

Ke mana ibu pergi?

Jawaban:

Ibu pergi ke kantor.

Emak pegi ke kantur/ngantur.

Pertanyaan:

Jak dimano selendang itu datang?

Dari mana selendang itu berasal ?

Jawaban:

Selendang itu jak Bengkulu.

Selendang itu berasal dari Bengkulu.

Jawaban dari pertanyaan-pertanyaan di atas adalah di Bengkulu, ke kantor, dan dari Bengkulu. Kata Kata itu merupakan keterangan tempat, jadi, kata tanya di mana, ke mana, dan dari mana digunakan untuk menanyakan tempat. Kata Ibu dalam bahasa Serawai Emak.

Penggunaan kata kebilo adalah bentuk kata tanya yang menyatakan kapan berada dilokasi/kedatangan ke suatu tempat. Kata kebilo lebih berkaitan dengan waktu. Kata kebilo banyak dipakai dimasyarakat Serawai Seluma.

\section{Kata Tanya Berapa}

Kata tanya berapa pada masyakat suku Serawai Seluma adalah menggunakan kata tanya begapo?. Kata ini menanyakan maksud berupa jumlah barang/benda atau biaya dalam bentuk upah/uang. Fungsi : Untuk menanyakan jumlah, barang/uang atau lebih bersifat ke nilai benda.

Pertanyaan:

Berapa umurnya?

Begapo umur kaba?

Jawaban:

Umurnya sebelas tahun.

Umur aku mbak kini 11 tahun.

Jawaban dari pertanyaan tersebut adalah sebelas tahun. Sebelas tahun menyatakan jumlah. jadi,kata tanya berapa digunakan untuk menanyakan jumlah. Kata tanya begapo sering dilakukan dalam pergaulan dan melibatkan kegiatan jual beli atau tawar menawar dalam masyarakat Serawai Seluma.

\section{Kata Tanya Bagaimana}

Kata tanya bagaiamana pada masyarakat suku Serawai Seluma adalah luakmano?. Kata luakmano biasanya dipakai untuk menanyakan bagaimana proses atau kronologi cara atau proses. Kata ini bermaksud ingin tahu atau bermaksud ingin lebih tahu.

Fungsi : untuk menanyakan keadaan.

Pertanyaan:

Luakmano cuaca saghini?

Bagaimana keadaan cuaca hari ini?

Jawaban:

Aghi ni cuaca o lagi ujan deghas.

Cuaca hari ini hujan deras

Jawaban dari pertanyaan tersebut adalah hujan deras. Hujan deras menyatakan keaadaanm jadi katanya tanya bagaimana digunakan untuk menanyakan keadaan. 
Penggunaan kata luakmano ini menunjukkan kegiatan proses atau tindakan melakukan sesuatu. Kata ini bertujuan untuk bertanya jika ketidakmampuan atau ketidakpahaman seseorang terhadap pekerjaan

\section{Kata Tanya Mengapa}

Pada masyarakat suku Serawai Seluma, kata mengapa adalah ngapo?. Kata ngapo bermaksud menanyakan ada ada dan apa alasannya? Fungsi: untuk menanyakan alasan-sebab.

\section{Pertanyaan:}

Ngapolah Pak Adi nido datang? Jawaban:

Mengapa Pak Abdi Tidak datang?

Pak Abdi Tidak datang mungkin karena sibuk atau ada pekerjaan yang tidak bisa ditinggalkan.

Kata mengapa dalam bahasa Serawai adalah: ngapo?. Jawaban dari pertanyaan tersebut adalah karena sibuk, karena sibuk merupakan alasan, jadi kata tanya mengapa/ ngapo digunakan untuk menanyakan alasan.

Kalimat adalah gabungan dari dua buah kata atau lebih yang menghasilkan suatu pengertian dan pola intonasi akhir. Kalimat dapat dibagi-bagi lagi berdasarkan jenis dan fungsinya yang akan dijelaskan pada bagian lain. Contohnya seperti kalimat lengkap, kalimat tidak lengkap, kalimat pasif, kalimat perintah, kalimat majemuk, dan lain sebagainya (Ali, 1991: 1).

Kalimat tanya adalah kalimat yang mengandung suatu permintaan agar kita diberitahu sesuatu karena kita tidak mengetahui sesuatu hal. Kalimat ini memiliki intonasi yang berbeda dengan pola intonasi kalimat berita. Perbedaannya terletak pada nada akhirnya. Pola intonasi kalimat berita bernada turun, sedangkan pola kalimat Tanya bernada akhir naik, di samping nada suku terakhir yang lebih tinggi sedikit dibandingkan dengan nada suku terakhir pola intonasi kalimat berita. Bila kita membandingkan kalimat tanya dengan kalimat berita maka terdapat beberapa ciri yang dengan tegas membedakannya dengan kalimat berita (Badudu, 2000: 5).

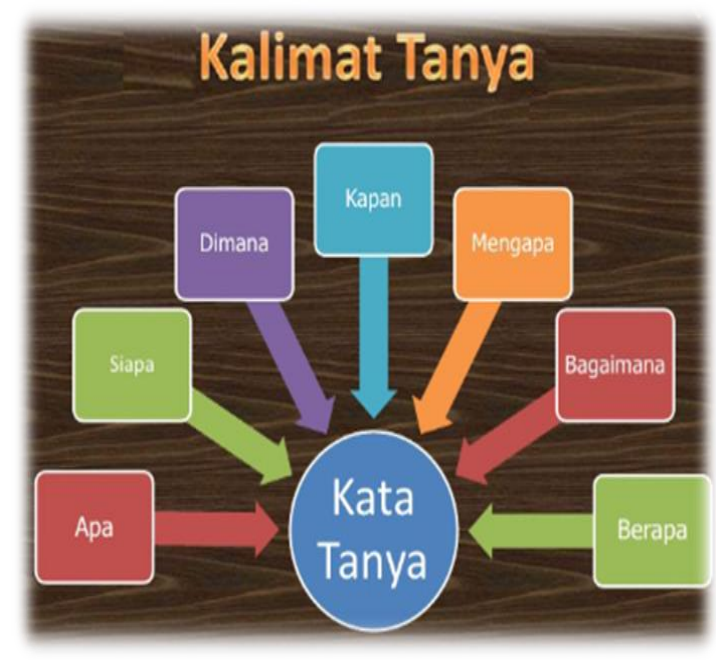

Gambar 1.1 Kalimat Tanya

\section{Simpulan}

Simpulan dalam penelitian ini adalah: kalimat interogatif dalam bahasa Serawai masyarakat Seluma kata tanya di, ke, dari menunjukkan (di, ke dan jakmano); kata tanya apa (dio); kata tanya siapa (sapo); kata tanya kapan (kebilo); kata tanya di, ke, dari (di, ke dan jak); kata tanya berapa (begapo); kata tanya bagaimana (luakmano); dan Kata tanya mengapa (ngapo). Jenis kata tanya tersebut berfungsi dan bertujuan untuk menanyakan sesuatu dan memerlukan jawaban atau tindakan. 


\section{Daftar Pustaka}

Ali, Lukman dkk, 1997. Petunjuk Praktis Berbahasa Indonesia. Jakarta: Pusat Pembinaan dan Pengembangan Bahasa.

Anton M. Moeliono. (edisi ketiga). 2003. Tata Bahasa Baku Bahasa Indonesia. Jakarta: Balai Pustaka.

Badudu, J.S. 1983. Membina Bahasa Indonesia Baku. Bandung: Pustaka Prima.

Chaer, Abdul. 1994. Linguistik Umum. Jakarta: Rineka Cipta.

Chaer, Abdul. 2008. Linguistik Umum. Jakarta: Rineka Cipta.

Chaer, Abdul. 2011. Tata Bahasa Praktis Bahasa Indonesia. Jakarta: Rineka Cipta.

Depertemen Pendidikan dan Kebudayaan. 2006. Kamus Besar Bahasa Indonesia. Jakarta: Depdikbud.

Dola, Abdullah. 2010. Tataran Sintaksis dalam Gramatika Bahasa Indonesia. Makassar: Badan Penerbit UNM.

Falah, M. Zaenal. 2008. Tata Bahasa Indonesia untuk SMTP-SMTAPerguruan Tinggi. Yogyakarta: CV Karyono.

Finoza, Lamuddin. 2002. Komposisi Bahasa Indonesia. Jakarta: Insan Mulia.

Kridalaksana, Harimurti. 2001. Kamus Linguistik. Edisi Ketia. Jakarta: PT Gramedia Pustaka Utama.

Kusharyanti. Et al. 2005. Pesona Bahasa Langkah Awal Memahami Linguistik. Jakarta: PT Gramedia Pustaka Utama.
Markhamah. 2014. Ragam dan Analisis Kalimat Bahasa Indonesia. Surakarta: Muhammadiyah University Press.

Ramlan, M. 1983. Morfologi Suatu Tinjauan Deskriptif. Yogyakarta: CV Karyono.

Razak, Abdul. 1985. Kalimat Efektif. Jakarta: Gramedia.

Subroto, Edi. 1992. Pengantar Metoda Penelitian Linguistik Struktural. Surakarta: Sebelas Maret University Press.

Sudaryanto. 2017. Metode dan Aneka Teknik Analisis Bahasa. Yogyakarta: M. L. I. Komisariat Universitas Gajah Mada.

Verhaar, J.W.M. 1996. Asas-Asas Linguistik Umum. Yogyakarta: Gadjah Mada University Press.

Zaim, M. 2014. Metode Penelitian Bahasa Metode Struktural. Padang: Universitas Negeri Padang. 